Section Editors

David C. Spencer, MD

Steven Karceski, MD

\title{
Sudden unexpected death in epilepsy
}

\section{Taking another look}

Stephan U. Schuele, MD, $\mathrm{MPH}$
WHAT CONDITION DID THE RESEARCHERS STUDY? The researchers set out to understand more about the condition of sudden death that can happen in people who have epilepsy (sudden unexpected death in epilepsy [SUDEP]). ${ }^{1}$ Epilepsy is a disorder of the brain. People who have had 2 seizures without a clear trigger or one seizure and a high risk of more seizures in the future have epilepsy. ${ }^{2}$ See the "About epilepsy" page for more information about epilepsy.

Patients with epilepsy are at a higher risk for death than otherwise healthy people. The cause of death in people with epilepsy is not always from injuries, drowning, or unusual prolonged seizures. Sometimes the underlying cause is the epilepsy itself. Some people with epilepsy have sudden death after a rather typical convulsion, and a small number even without a preceding seizure. The risk for SUDEP is low, affecting 1 in 100-1,000 patients per year. ${ }^{3,4}$ For over a decade, SUDEP has brought affected family members and medical professionals together in their passion to fight this dreadful event. Our goals are to raise awareness of SUDEP, to improve patient education, to understand the extent of the problem and risk factors, and to find ways to prevent SUDEP. Before we look at what the researchers did, a few definitions are important ${ }^{5}$ :

1. Definite SUDEP is a sudden death in someone with epilepsy without an alternative cause of death.

2. Definite SUDEP plus means that there is SUDEP with a contributing medical condition.

3. Possible SUDEP means that there is a competing cause of death, so there is less certainty about the SUDEP label.

4. No SUDEP is the term used when there is a clear alternative reason for death.

HOW DID THE RESEARCHERS STUDY THIS ISSUE? SUDEP is the sudden death of someone with epilepsy who is otherwise in good health. In these cases, autopsies do not indicate another cause of death. In this article, the authors researched medical records to assess reporting of death due to SUDEP.

California law requires that all deaths outside the hospital are reported to the medical examiner. As part of a study in San Francisco, a group of heart specialists and pathologists identified all sudden cardiac death (SCD) cases from February 2011 to March 2014, Dr. Devinsky, who is also the lead investigator of the North American SUDEP Registry, and his group went back to review all cases of SCD who had a history of seizures or epilepsy to determine if the cause of death was possibly related to SUDEP. ${ }^{1}$

WHAT WERE THE RESULTS? The San Francisco study included 525 cases of sudden cardiac deaths in patients who had an autopsy and complete records. They found 39 cases-around 7\%-with a history of seizures. At first, 15 of the 39 were thought to have epilepsy and 6 were classified as definite SUDEP. When Dr. Devinsky and his group looked through the records, they determined that 25 of the 39 cases with a seizure history actually had epilepsy. They found 2 more cases that had definite SUDEP plus and 10 cases of possible SUDEP. There were 14 remaining cases that did not have epilepsy, but instead had provoked seizures. An acute provoked seizure was considered as possibly contributing to death in 5 . In the end, 12 out of 18 definite or possible SUDEP cases went unrecognized.

WHAT DO THE RESULTS MEAN? Although researchers have tried to define epilepsy and SUDEP, nonepilepsy experts are not consistent in recognizing SUDEP. This affects some patients who have another cause of death. SUDEP plus and possible SUDEP cases may not be reported. This problem is more common in older people, or others with medical conditions or substance abuse. This means that the frequency of SUDEP is not correct and that risk factors are not noticed. If they are not noticed, they cannot be treated.

Until there is a test or biomarker to verify SUDEP, we need to continue helping all health care professionals to recognize and correctly classify cases of SUDEP.

\section{REFERENCES}

1. Devinsky O, Friedman D, Cheng JY, Moffatt E, Kim A, Tseng $\mathrm{ZH}$. Underestimation of sudden deaths among patients with seizures and epilepsy. Neurology 2017;89:886-892.

2. Fisher RS, Acevedo C, Arzimanoglou A, et al. A practical definition of epilepsy. Epilepsia 2014;55:475-482. 
3. Lhatoo S, Noebels J, Whittemore V; NINDS Center for SUDEP Research. Sudden unexpected death in epilepsy: identifying risk and preventing mortality. Epilepsia 2015; 56:1700-1706.

4. Harden C, Tomson T, Gloss D, et al. Practice guideline summary: sudden unexpected death in epilepsy incidence rates and risk factors: report of the Guideline
Development, Dissemination, and Implementation Subcommittee of the American Academy of Neurology and the American Epilepsy Society. Neurology 2017;88: 1674-1680.

5. Nashef L, So EL, Ryvlin P, Tomson T. Unifying the definitions of sudden unexpected death in epilepsy. Epilepsia 2012;53:227-233. 


\section{PATIENT PAGE}

Section Editors

\section{About epilepsy}

David C. Spencer, MD

Steven Karceski, MD

Stephan U. Schuele, MD, Adapted from: Vossler DG. Antiepileptic drugs: are $\mathrm{MPH}$

generics as effective as brand name? Neurology 2016;87:e211-e214.

Epilepsy is a brain condition that causes seizures from time to time. There is not just one type of epilepsy, but rather there are about 40 different types of epilepsy. Doctors use several pieces of information to determine the type of epilepsy:

1. Age at seizure onset

2. Seizure types

3. Pattern on brain wave electrical recording (EEG)

4. Findings from brain imaging using MRI

5. Abnormalities in the person's neurologic examination

6. Family medical history of epilepsy

7. Presence of any other brain or general physical condition

8. Results of memory and intelligence tests

9. Identification of things that trigger seizures

10. Assessment of which medications help or worsen the seizures and help define the epilepsy type

Epilepsy is common. It is present in 1 of 120 people around the world. It affects all races and sexes equally. By age 80 years, 1 in 26 people will have had epilepsy and 1 in 10 will have had at least 1 seizure. Epilepsy is sometimes called a seizure disorder by patients and general doctors. Some persons with epilepsy like to use that term when they tell friends, coworkers, or family about their condition. The more accurate term is epilepsy. This term recognizes that there often are other problems besides the seizures. Having epilepsy almost always means the patient has to take medications, which may have side effects including tiredness, dizziness, and others.

Persons with epilepsy also often have other concerns such as depression, anxiety, and stress. Memory problems, job difficulties, dating/marriage/ fertility issues, social isolation, inability to drive under state laws, and limited finances are among other common concerns in people with epilepsy. Thus epilepsy is more than a seizure disorder for most people.

\section{ADDITIONAL RESOURCES}

\section{Neurology Now ${ }^{\circledR}$}

journals.lww.com/neurologynow/Pages/Resource-Central. asp $x$

Epilepsy Foundation SUDEP Institute epilepsy.com/get-helplabout-sudep-institute

Center for SUDEP Research

csr.case.edu/index.php/Main_Page 


\section{Neurology}

\section{Sudden unexpected death in epilepsy: Taking another look \\ Stephan U. Schuele \\ Neurology 2017;89;e117-e119 \\ DOI 10.1212/WNL.0000000000004351}

This information is current as of August 28, 2017

\section{Updated Information \& Services}

References

Subspecialty Collections

Permissions \& Licensing

\section{Reprints}

including high resolution figures, can be found at: http://n.neurology.org/content/89/9/e117.full

This article cites 5 articles, 2 of which you can access for free at: http://n.neurology.org/content/89/9/e117.full\#ref-list-1

This article, along with others on similar topics, appears in the following collection(s):

All Epilepsy/Seizures

http://n.neurology.org/cgi/collection/all_epilepsy_seizures Epilepsy monitoring

http://n.neurology.org/cgi/collection/epilepsy_monitoring_ Epilepsy semiology

http://n.neurology.org/cgi/collection/epilepsy_semiology

Information about reproducing this article in parts (figures,tables) or in its entirety can be found online at:

http://www.neurology.org/about/about_the_journal\#permissions

Information about ordering reprints can be found online:

http://n.neurology.org/subscribers/advertise

Neurology ${ }^{\circledR}$ is the official journal of the American Academy of Neurology. Published continuously since 1951, it is now a weekly with 48 issues per year. Copyright (O 2017 American Academy of Neurology. All rights reserved. Print ISSN: 0028-3878. Online ISSN: 1526-632X.

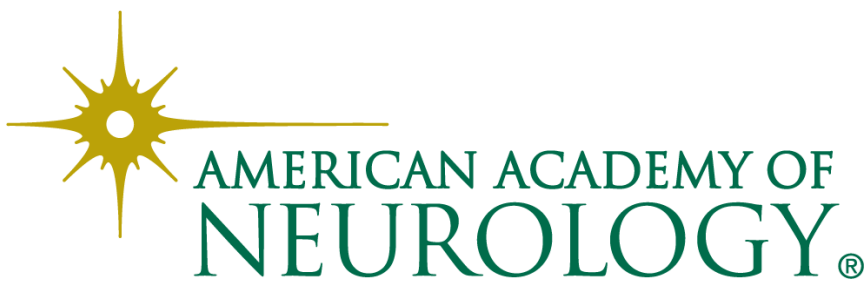

